PROFESI (Profesional Islam): Media Publikasi Penelitian

2019; Volume 16; No 2.

Website: ejournal.stikespku.ac.id

\title{
Manfaat Massage Tengkuk Dengan Minyak Zaitun Untuk Mengurangi Nyeri Kepala Pasien Hipertensi
}

\author{
Nuzul Eka Yoganita ${ }^{1 *}$, Siti Sarifah ${ }^{2}$, Yuli Widyastuti ${ }^{3}$ \\ ${ }^{1,2,3}$ Prodi DIII Keperawatan, STIKES PKU Muhammadiyah Surakarta \\ *Email: nuzuleka14@gmail.com
}

\begin{abstract}
Kata Kunci Abstrak
Massage Hipertensi atau tekanan darah tinggi adalah suatu peningkatan tekanan darah di Tengkuk; dalam arteri. Prevalensi hipertensi di Indonesia sebesar 26,5 persen dari total Minyak penduduk di Indonesia. Studi pendahuluan di dapatkan sebanyak 18 orang yang Zaitun; mengalami hipertensi dengan nyeri kepala. Tujuan penelitian ini untuk mengetahui Nyeri manfaat terapi massage tengkuk dengan minyak zaitun untuk mengurangi nyeri pada Kepala; $\quad$ pasien hipertensi. Penelitian ini merupakan penelitian kuantitatif dengan desain Quasi Hipertensi Eksperimental design rancangan One Group Pretest Posttest dengan teknik sampling purposive sampling sejumlah 14 responden. Instrumen penelitian menggunakan skala nyeri numerik, sphygmomanometer dan minyak zaitun. Analisa data menggunakan Uji Wilcoxon Signed Rank Test dengan signifikansi 5\%. Dengan hasil terdapat pengaruh massage tengkuk dengan minyak zaitun dalam mengurangi nyeri kepala pasien hipertensi dengan nilai $p$ value 0.001 ( $p<0.050)$.
\end{abstract}

\section{The Benefits of Nape Massage With Olive Oil To Reduce Headache on Hypertension Patients}

\begin{abstract}
Key Words:
Nape

Massage;

Olive Oil;

Headache;

Hypertension

Abstract

Hypertension or high blood pressure is an increase blood pressure in the arteries. The prevalence of hypertension in Indonesia is 26.5 percent of the total population in Indonesia. In preliminary study there were as many as 18 people who have hypertension with headache. The purpose of the research is to know the benefits of nape massage therapy with olive oil to reduce pain in hypertension patients. This research was a quantitative research with Quasi Experimental design of One Group Pretest Posttest with sampling technique purposive sampling number of 14 respondents. The research instrument used numerical pain scale, sphygmomanometer and olive oil. Data analysed using Wilcoxon Signed Rank Test with significance 5\%. With outcome there is an effect of nape massage with olive oil in reducing headache of hypertension patients with $p$ value 0.001 ( $p$ <0.050).
\end{abstract}

\section{PENDAHULUAN}

Hipertensi atau tekanan darah tinggi adalah suatu peningkatan tekanan darah di dalam arteri. Secara umum, hipertensi merupakan suatu keadaan tanpa gejala, dimana tekanan yang abnormal tinggi di dalam arteri menyebabkan meningkatnya resiko terhadap stroke, aneurisma, gagal jantung, dan kerusakan ginjal. Dikatakan tekanan darah tinggi jika pada saat duduk tekanan sistolik mencapai $140 \mathrm{mmHg}$ atau lebih, atau tekanan diastolik mencapai $90 \mathrm{mmHg}$ atau lebih, atau tekanan keduanya (Ruhyanudin, 2007).
Data World Health Organization (WHO) tahun 2011 menunjukkan satu milyar orang di dunia menderita Hipertensi, 2/3 diantaranya berada di negara berkembang yang berpenghasilan rendah sampai sedang. Prevalensi Hipertensi akan terus meningkat tajam dan diprediksi pada tahun 2025 sebanyak $29 \%$ orang dewasa di seluruh dunia terkena Hipertensi (Depkes, 2017). Prevalensi hipertensi di Indonesia sebesar 26,5 persen $(25,8 \%+0,7 \%)$ (Riskesdas, 2013). Hasil pengukuran tekanan darah di Jawa Tengah, sebanyak 344.033 orang atau 17,74 persen dinya- 
takan hipertensi/tekanan darah tinggi (Dinas Kesehatan Jawa Tengah, 2015). Kasus yang ditemukan di Surakarta pada tahun 2014 dari laporan Puskesmas sebanyak 65.252 kasus (hipertensi essensial) (Dinkes Surakarta, 2014).

Gejala klinis hipertensi yang sering timbul menurut Corwin (2009) antara lain nyeri kepala saat terjaga, kadang-kadang disertai mual dan muntah akibat peningkatan tekanan darah intrakranial, penglihatan kabur akibat kerusakan retina, ayunan langkah yang tidak mantap karena kerusakan susunan saraf pusat, nokturia karena peningkatan aliran darah ginjal dan filtrasi glomelorous, edema dependen dan pembengkakan akibat peningkatan tekanan kapiler.

Salah satu gejala klinis hipertensi adalah adanya nyeri khususnya area leher, tengkok sampai ke kepala. Tindakan untuk mengurangi nyeri menurut Kozier, dkk (2011), mencakup tindakan non farmakologis dan tindakan farmakologis. Tindakan farmakologis dengan penggunaan obat-obat analgesik. Tindakan non farmakologis antara lain stimulasi kutaneus, pijat (massage), aplikasi panas dingin, akupresur, stimulasi kontralateral, imobilisasi, stimulasi saraf elektrik transkutaneus, distraksi, relaksasi, meditasi, hipnosis. Massage merupakan salah satu penatalaksanaan yang dapat menurunkan nyeri.

Menurut Dalimartha (2008) dalam Wijaya dan Putri (2013), pada prinsipnya massage yang dilakukan pada penderita hipertensi adalah untuk memperlancar aliran energi dalam tubuh sehingga gangguan hipertensi dan komplikasinya dapat diminalisir. Nyeri kepala yang biasa terjadi pada hipertensi dapat diberikan intervensi dengan massage. Menurut Snyder dan Linquist (2009) dalam Subandiyo (2014), terapi pijat tengkuk hanya menggunakan tangan manusia. Tekanan terhadap kutan dan jaringan subkutan melepaskan histamin yang pada akhirnya akan menghasilkan vasodilator pembuluh darah dan meningkatkan aliran balik vena yang kemudian akan menurunkan kerja jantung. Terjadinya penurunan kerja jantung, maka tekanan intrakranial akan menjadi turun. Nyeri kepala akan menjadi lebih berkurang.
Prosedur pemijatan, gunakan minyak zaitun di tangan dan digosok-gosokan dengan kedua tangan, Memijat area tengkuk menggunakan telapak tangan dengan 20 gerakan maju mundur ke arah samping kiri dengan posisi di sebelah kanan responden diulang beberapa kali, Memijat dengan cara seperti mencubit kulit tengkuk responden sebanyak 20 gerakan, Posisi berpindah di belakang responden. Memijat tengkuk dengan cara linier dari atas ke bawah menggunakan ibu jari dan gerakan dari bawah ke atas menggunakan telapak tangan sebanyak 20 gerakan, Membersihkan sisa minyak zaitun di tubuh responden. Dilakukan duakali sehari pagi dan sore.

Minyak zaitun memiliki kandungan vitamin E yang berguna untuk melembabkan kulit saat dioleskan serta memiliki kandungan polifenol yang berguna sebagai antiinflamasi saat meresap ke dalam pori-pori kulit sehingga menurunkan nyeri (Yana, 2014). Vitamin larut lemak yang banyak terdapat di dalam minyak zaitun adalah vitamin E. Nama lain dari vitamin E adalah tokoferol. Di dalam tubuh, vitamin E disimpan dalam hati dan lemak tubuh untuk waktu yang lama sehingga tidak perlu dikonsumsi setiap kali makan. Kadar vitamin E dalam minyak zaitun termasuk tinggi. Vitamin $\mathrm{E}$ berfungsi untuk meningkatkan daya tahan tubuh, membantu mengatasi stres, meningkatkan kesuburan, serta meminimalkan risiko penyakit kanker dan penyakit jantung koroner. Selain itu, vitamin E juga sangat bermanfaat bagi kesehatan kulit, bermanfaat sebagai antioksidan untuk penangkal radikal bebas, serta melindungi sel darah merah dari kerusakan (Adam (2013), dalam Astawan, dkk (2015).

Tujuan umum penelitian ini adalah untuk mengetahui manfaat massage tengkuk dengan minyak zaitun dalam mengurangi nyeri kepala pasien hipertensi, dengan tujuan khusus yaitu untuk mengetahui skala nyeri kepala sebelum dan sesudah diberikan perlakuan dan untuk menganalisis perbedaan tingkat nyeri kepala. Untuk mengetahui tingkat nyeri pada pasien hipertensi setelah diberikan tindakan massage tengkuk dengan minyak zaitun, Untuk menganalisa perbedaan tingkat nyeri pada pasien hipertensi 
PROFESI (Profesional Islam): Media Publikasi Penelitian 2019; Volume 16; No 2.

Website: ejournal.stikespku.ac.id

sebelum dan sesudah diberikan tindakan massage tengkuk dengan minyak zaitun

\section{METODE PENELITIAN}

Jenis penelitian ini adalah penelitian kuantitatif. Penelitian ini menggunakan desain Quasi Eksperimental design rancangan One Grup Pretest Posttest dengan tekhnik sampling purposive sampling didapatkan sejumlah 14 responden dengan kriteria responden hipertensi tahap 1 dan 2, mengalami nyeri kepala sedang skala 4 6 , dan sedang tidak mengkonsumsi obat. Penelitian dilakukan di RT 3/6 Jajar kota Surakarta pada tanggal 21 - 28 Desember 2017. Instrumen penelitian yang digunakan antara lain sphygmomanometer jarum, skala nyeri numerik, alat tulis, lembar observasi nyeri dan minyak zaitun. teknik pengumpulan data menggunakan metode wawancara dan observasi. Variabel penelitian ini adalah massage tengkuk dengan minyak zaitun dan nyeri kepala. Analisis data penelitian ini menggunakan Uji Wilcoxon Signed Rank Test.

\section{HASIL DAN PEMBAHASAN}

a. Hasil

Penelitian ini dilakukan kepada 14 responden dengan nyeri kepala hipertensi dan didapatkan hasil sebagai berikut:

1) Analisis Univariat

a) Jenis Kelamin

Tabel 1. Karakteristik Responden Berdasarkan Jenis Kelamin

\begin{tabular}{ccc}
\hline Jenis kelamin & Frekuensi & $\begin{array}{c}\text { Persentase } \\
(\%)\end{array}$ \\
\hline Laki-laki & 3 & 21.4 \\
Perempuan & 11 & 78.6 \\
Total & 14 & 100.0 \\
\hline
\end{tabular}

Berdasarkan Tabel 1 diketahui bahwa sebagian besar responden berjenis kelamin perempuan $(78.6 \%)$. b) Usia

Tabel 2. Karakteristik Responden Berdasarkan Usia

\begin{tabular}{ccc}
\hline Rentang usia & Frekuensi & $\begin{array}{c}\text { Persentase } \\
(\%)\end{array}$ \\
\hline $41-50$ & 4 & 28.6 \\
$51-60$ & 5 & 35.7 \\
$61-70$ & 4 & 28.6 \\
$<70$ & 1 & 7.1 \\
Total & 14 & 100.0 \\
\hline
\end{tabular}

Berdasarkan Tabel 2 diketahui bahwa sebagian besar responden berusia $51-60$ tahun $(35.7 \%)$, kemudian 41 - 50 tahun dan 61 - 70 tahun (28.6).

c) Tingkat Pendidikan

Tabel 3. Karakteristik Responden Berdasarkan Tingkat Pendidikan

\begin{tabular}{ccc}
\hline $\begin{array}{c}\text { Tingkat } \\
\text { Pendidikan }\end{array}$ & Frekuensi & $\begin{array}{c}\text { Persentase } \\
(\%)\end{array}$ \\
\hline SD & 10 & $71.4 \%$ \\
SMP & 3 & $21.4 \%$ \\
SMK & 1 & $7.1 \%$ \\
Total & 14 & $100.0 \%$ \\
\hline
\end{tabular}

Berdasarkan Tabel 3 diketahui bahwa sebagian besar responden memiliki tingkat pendidikan SD (71.4\%).

d) Skala Nyeri Pretest

Tabel 4. Skala Nyeri Pretest

\begin{tabular}{ccc}
\hline \multirow{2}{*}{ Skala Nyeri } & \multicolumn{2}{c}{ Skala nyeri pre H-1 } \\
Frekuensi & $\begin{array}{c}\text { Persentase } \\
(\%)\end{array}$ \\
\hline 4 & 7 & 50.0 \\
5 & 5 & 35.7 \\
6 & 2 & 14.3 \\
Total & 14 & 100.0 \\
\hline
\end{tabular}

Berdasarkan Tabel 4 diketahui bahwa skala nyeri kepala sebelum diberikan perlakuan 
sebagian besar memiliki skala nyeri 4 $(50 \%)$ dan tertinggi skala nyeri $6(14.3 \%)$.

e) Skala Nyeri Posttest

Tabel 5. Skala Nyeri Posttest

\begin{tabular}{cll}
\hline Skala & \multicolumn{2}{c}{ Skala nyeri post H-3 } \\
nyeri & Frekuensi & Persentase $(\%)$ \\
\hline 3 & 13 & 92.9 \\
4 & 1 & 7.1 \\
Total & 14 & 100.0 \\
\hline
\end{tabular}

Berdasarkan Tabel 5 diketahui bahwa skala nyeri kepala setelah diberikan perlakuan memiliki skala nyeri 3 (92.9\%) dan skala nyeri $4(7.1 \%)$.

2) Analisa Bivariat

Tabel 6. Uji Statistik Skala Nyeri Pretest dan Posttest

\begin{tabular}{ll}
\hline & Test Statistics \\
& Skala Nyeri Post H-3 - \\
& Skala Nyeri Pre H-1 \\
\hline Z & $-3.376^{\text {b }}$ \\
Asymp. Sig. & .001 \\
(2-tailed) & \\
\hline
\end{tabular}

Berdasarkan Tabel 6 diketahui bahwa dengan Uji Wilcoxon, skala nyeri sebelum dan sesudah diberikan massage tengkuk dengan minyak zaitun memperoleh nilai $\mathrm{Z}$ hitung 3.376 ( $Z$ hitung $>Z$ tabel 0.0004) dimana nilai probabilitas $0.04 \%$ dan nilai $\mathrm{p}$ value signifikansi $0.001(\mathrm{p}<0.050)$ dengan nilai probalitas lemah $(0.04 \%)$ dimana terdapat nilai kemaknaan kecil.

b. Pembahasan

1) Karakteristik jenis kelamin responden

Hasil penelitian menunjukan pembagian responden berdasarkan jenis kelamin menunjukan sebagian besar berjenis kelamin perempuan yaitu 11 responden (78.6\%). Berdasarkan hasil penelitian dapat diketahui bahwa pemberian perlakuan lebih efektif diberikan kepada responden perempuan dengan penu- runan skala nyeri hingga 3 skala dibandingkan dengan laki-laki yang hanya terjadi penurunan hanya 1 skala. Perempuan lebih mampu dalam mengungkapkan persepsi nyeri dikarenakan dalam beberapa kebudayaan menganggap bahwa seorang laki-laki harus lebih berani dibandingkan perempuan (Kozier, dkk, 2011).

Teori lain menyatakan laki-laki memiliki sensitifitas yang lebih rendah (kurang mengekspresikan nyeri yang dirasakan secara berlebihan) dibandingkan wanita atau kurang merasakan nyeri ( Black \& Hawks, 2014).

2) Karakteristik responden berdasarkan usia

Hasil penelitian menunjukan sebagian besar responden berada pada rentang usia 41 50 tahun, ada 5 responden (35.7\%), dan sebagian kecil responden berada pada rentang usia $71-80$ tahun sejumlah 1 responden $(7.1 \%)$. Berdasarkan penelitian dapat diketahui bahwa pemberian perlakuan lebih efektif diberikan kepada responden usia 61 - 70 tahun dimana terjadi penurunan skala nyeri hingga 2 skala dan usia $>70$ tahun dengan penurunan skala nyeri hingga 3 skala. Tahap perkembangan pada usia lansia dapat terjadi penurunan sensasi atau persepsi nyeri, serta menganggap bahwa rasa nyeri sebagai bagian dari proses penuaan (Kozier, dkk, 2011). Teori lain menyatakan bahwa lansia berespon terhadap nyeri dapat berbeda dibandingkan dengan orang yang berusia lebih muda cara beresponnya (Smeltzer \& Bare, 2013). Usia semakin tua akan lebih bisa menerima sebagai sesuatu yang harus diterima dibandingkan usia yang lebih muda ketika merespon adanya nyeri yang dirasakan.

3) Karakteristik responden berdasarkan tingkat pendidikan

Hasil penelitian menunjukan sebagian besar responden memiliki tingkat pendidikan SD sebanyak 10 responden (71.4\%) dan sebagian kecil responden memiliki tingkat pendidikan SMK sebanyak 1 responden (7.1\%). Tingkat pendidikan mempengaruhi koping individu terhadap pengetahuan seseorang dalam mengantisipasi dan menangani nyeri. 
Semakin tinggi pengetahuan dimiliki semakin baik pula koping individu dalam menangani nyeri (Smeltzer dan Bare, 2013).

4) Penurunan intensitas nyeri responden

a) Sebelum tindakan massage tengkuk dengan minyak zaitun

Hasil penelitian sebelum dilakukan tindakan massage tengkuk dengan minyak zaitun pada hari pertama terdapat 14 responden yang sebagian besar mengalami nyeri kepala dengan skala nyeri 4 sejumlah 7 responden (50\%), dan sebagian kecil mengalami nyeri kepala dengan skala nyeri 6 sejumlah 2 responden (14.3\%).

b) Setelah tindakan massage tengkuk dengan minyak zaitun

Nyeri kepala yang biasa terjadi pada hipertensi dapat diberikan intervensi dengan massage. Menurut Snyder dan Linquist (2009) dalam Subandiyo (2014), terapi pijat tengkuk hanya menggunakan tangan manusia. Tekanan terhadap kutan dan jaringan subkutan melepaskan histamin yang pada akhirnya akan menghasilkan vasodilator pembuluh darah dan meningkatkan aliran balik vena yang kemudian akan menurunkan kerja jantung. Terjadinya penurunan kerja jantung, maka tekanan intrakranial akan menjadi turun. Nyeri kepala akan menjadi lebih berkurang.

Minyak zaitun memiliki kandungan vitamin E yang berguna untuk melembabkan kulit saat dioleskan serta memiliki kandungan polifenol yang berguna sebagai antiinflamasi saat meresap ke dalam poripori kulit sehingga menurunkan nyeri (Yana, 2014).

Berdasarkan penelitian yang dilakukan dengan perlakuan tindakan massage tengkuk dengan minyak zaitun pada hari ketiga menunjukan sebagian besar responden mengalami penurunan skala nyeri kepala menjadi skala nyeri 3 sejumlah 13 responden (92.9\%) dan 1 responden (7.1\%) dengan hasil skala nyeri 4. Berdasarkan penelitian selama tiga hari, dapat diketahui bahwa sebagian besar responden mengalami penurunan skala dan intensitas nyeri kepala. Uji Wilcoxon menunjukan nilai $\mathrm{Z}$ hitung -3.376 ( $\mathrm{Z}$ hitung $>\mathrm{Z}$ tabel 0.0004) dimana nilai probabilitas $0.04 \%$ dan nilai $p$ value signifikansi $0.001(\mathrm{p}<0.050)$ dengan ini menunjukan bahwa Ho ditolak dan $\mathrm{Ha}$ diterima dengan nilai probabilitas lemah $(0.04 \%)$ dimana terdapat nilai kemaknaan kecil. Jadi, dapat disimpulkan terdapat pengaruh massage tengkuk dengan minyak zaitun dalam mengurangi nyeri kepala pasien hipertensi.

Pemijatan adalah teknik penyembuhan alternatif untuk mengurangi ketegangan, meningkatkan sirkulasi, dan mempromosikan fungsi alami dari tubuh melalui penerapan tekanan di berbagai titik-titik tertentu pada tubuh. Ilmu ini berasal dari Cina. Pijat refleksi dapat dilakukan dengan tangan dan benda-benda lain berupa kayu, plastik, atau karet. Berdasarkan jurnal penelitian Widyastuti (2015) bahwa pemijatan dapat meningkatkan sirkulasi, sehingga tekanan darah, ketegangan otot dapat menjadi rileks. Penelitian yang sama juga dilakukan oleh Noudeh, dkk (2012) dengan judul "Penurunan Nyeri Kepala Migrain dengan Manipulasi Pijat Leher dan Tulang Belakang" menunjukan hasil setelah diberikan perlakuan tersebut intensitas nyeri kepala telah berkurang secara signifikan dibandingkan sebelum diberikan perlakuan. Penelitian ini menunjukan bahwa penerapan massage dan manipulasi servikal dan torakal dapat menurunkan intensitas nyeri kepala pada pasien dengan nyeri kepala migrain. Menurut Snyder dan Linquist (2009) dalam Subandiyo (2014), terapi pijat tengkuk hanya menggunakan tangan manusia.

Tekanan terhadap kutan dan jaringan subkutan melepaskan histamin yang pada akhirnya akan menghasilkan vasodilator pembuluh darah dan meningkatkan aliran 
PROFESI (Profesional Islam): Media Publikasi Penelitian 2019; Volume 16; No 2.

Website: ejournal.stikespku.ac.id

balik vena yang kemudian akan menurunkan kerja jantung. Terjadinya penurunan kerja jantung, maka tekanan intrakranial akan menjadi turun. Nyeri kepala akan menjadi lebih berkurang.

\section{SIMPULAN}

Berdasarkan penelitian dan analisis data, maka dapat ditarik kesimpulan terdapat perbedaan skala nyeri kepala sebelum dan sesudah diberikan massage tengkuk dengan minyak zaitun dimana terjadi penurunan skala nyeri kepala.

Penelitian ini diharapkan dapat menambah pengetahuan dan dijadikan sebagai pertimbangan referensi dalam penelitian masa depan dan diharapkan masyarakat untuk dapat menerapkan pemnafaatan massage tengkuk dengan minyak zaitun.

\section{REFERENSI}

Black, J.M., Hawks, J.H. (2014). Medical Surgical Nursing Clinical Management for Positive Outcomes, $\left(7^{\text {th }}\right.$ ed), St. Louis, Missouri, Elsevier Saunders

Corwin, E. J. (2009). Buku Saku Patofisiologi edisi Revisi 3. Jakarta: EGC.

Depkes. (2017). Sebagian Besar Pasien Hipertensi Tidak Menyadarinya. Online (www.

depkes.go.id/article/view/17051800002/s ebagian-besar-penderita-hipertensitidak-menyadarinya.html). Diakses tanggal 26 Oktober 2017 pukul 12:30.

Dinas Kesehatan Jawa Tengah. (2015). Profil Kesehatan Jawa Tengah tahun 2015. Semarang: Dinas Kesehatan Jawa Tengah.

Dinkes Surakarta. (2014). Profil Kesehatan Kota Surakarta tahun 2014. Surakarta: Dinas Kesehatan Surakarta.
Kozier, B., Erb, G., Berman, A., Snyder, S. J. (2011). Buku Ajar Fundamental Keperawatan Konsep, Proses, dan Praktik Volume 2. Alih Bahasa oleh Esty W., Devi Y., Yuyun Y., Ana L. 2010. Jakarta: EGC.

Notoatmodjo, S. (2012). Metodologi Penelitian Kesehatan. Jakarta : PT Rineka Cipta

Noudeh, Y. J., Vatankhah, N., Baradaran, H. R. (2012). Penurunan Nyeri Kepala Migrain dengan Menggunakan Pijat Leher dan Manipulasi Spinal. International Journal of Therapeutic Massage and Bodywork. 5 (1).

Ruhyanudin, F. (2007). Asuhan Keperawatan Pada Klien Dengan Gangguan Sistem Kardiovaskuler edisi Revisi. Malang: UPT. Penerbitan Universitas Muhammadiyah Malang.

Riskesdas. (2013). Riset Kesehatan Dasar. Jakarta: Kementrian Kesehatan RI.

Smeltzer, S. C., Bare, B. G. (2013). Buku Ajar Keperawatan Medikal-Bedah Brunner \& Suddarth Vol 1. Alih Bahasa oleh Agung W., Karyasa I., Julia. 2013. Jakarta: EGC.

Subandiyo. (2014). Pengaruh Pijat Tengkuk dan Hipnotis Terhadap Penurunan Tekanan Darah pada Pasien Hipertensi. Jurnal Keperawatan Soedirman. 9 (3).

Wijaya, A. S., Putri Y. M. (2013). KMB Keperawatan Medikal Bedah (Keperawatan Dewasa). Yogyakarta: Nuha Medika.

Yana, Y. (2014). 41 Manfaat Minyak Zaitun bagi Kesehatan, Kecantikan, dan Efek Sampingnya. Online (https://manfaat. co.id/manfaat-minyak-zaitun). Diakses tanggal 26 Oktober 2017 pukul 13:00. 